\title{
3次元簡易都市キャノピーモデルの構築と 屋外縮小模型都市を用いた実験
}

\section{A SIMPLE 3-DIMENSIONAL URBAN ENERGY BALANCE MODEL AND OUTDOOR SCALE MODEL EXPERIMENTS}

\author{
河合 徹 1 - 金賀 将彦 2 - 神田 学3 \\ Toru KAWAI, Masahiko KANEGA and Manabu KANDA

\begin{abstract}
1学生会員 工修 東京工業大学 理工学研究科国際開発工学専攻（广182-0082 東京都目黒区大岡山 2-12-1 東京工業大学 石川台4号館403号室)
\end{abstract} \\ 2学生会員 東京工業大学 理工学研究科国際開発工学専攻 ( \\ 3 正会員 工博 東京工業大学 理工学研究科国際開発工学専攻（

$\begin{array}{ll}\text { 同上 } & \\ \text { 同上 } & \text { ) }\end{array}$

\begin{abstract}
A Simple 3-dimensional Urban canopy Model for Meso-scale simulation (SUMM) was proposed. The model predicts the energy balance of constituent faces (roof, floor and 4 vertical walls) without time-consuming iterations. In the model, complex 3-dimensional radiation processes (multi-reflection processes) are theoretically solved, resulting in a large reduction of computational time. As for the turbulent transfers, the network of resistance is adopted. We also conducted outdoor scale model experiments having the similar geometric structure with SUMM, to construct the databases (energy balances and surface temperatures) for model validation, and to examine unknown model parameters (e.g. turbulent transfer coefficients).
\end{abstract}

Key Words : 3-dimensional, Outdoor Scale Model Experiment, SUMM, Bulk Transfer Coefficient Urban Energy Balance Model

\section{1. はじめに}

従来、気象モデルにおける都市部の底面条件には、都 市の幾何構造(凸凹)を粗度として捉える’平板モデル’゙ 用いられてきた。しかしながら、都市建物群落による起 伏は上空大気に複雑な影響を及ぼしており、簡易的な平 板モデルを用いて都才の起伏に起因する複雑は物理過程 を適切に評価することは難しい。このため、都市が上空 大気に及ぼす影響を適切に評価するためには、都市キャ ノピー層の物理過程をより詳細に再現する地表面スキー ムの構築が不可欠である。一方、建物周辺の物理過程を 詳細に予測する所謂CFDモデルは、現状では非常に大き な計算負荷を要すため、これを気象モデルへ直接適用す ることは現実的でない。以上の観点から、近年簡易的な 都市キャノピーモデルの構築が行われている1), 2), 3) 4)。こ れらは都市の幾何構造に起因する物理過程(放射のト ラッピングの影響等)を陽的に表現する極めて先駆的な 研究ではあるが、無限に長い2次元のストリートキャニ オンを仮定した簡易的なものであり、都市の3次元構造 を表現するには簡略化されすぎている。例えば、2次元 モデルを3次元構造に適用した場合、キャノピーアルベ
ドを過小評価すること5)や、2次元構造と3次元構造では 乱流熱輸送効率(対流熱伝達率)が大きく異なることが指 摘されている6)。そこで、本論では都市幾何構造の3次 元性を考慮した簡易都市キャノピーモデル $S U M M$ (Simple Urban canopy Model for Meso-scale simulation) を提 案する。3次元幾何構造を対象とした場合、放射の取り 扱い(日的、日陰形成等)が2次元構造に比べて格段に複雑 になる。このため、3次元放射収支計算は通常非常に大 きな計算負荷を要すが、本論では複雑な3次元放射過程 を解析的に処理する手法を導入し ${ }^{4)}$ 、計算負荷を大幅に 削減している。3次元放射過程を解析的に処理すること により、SUMMでは2次元モデル同様、極めて低計算負 荷で構成面別(4鉛直壁面、屋根面、床面)の熱収支、及び 表面温度を予測することができる。

一方、SUMMの検証、及び未知モデルパラメーター (バルク輸送係数)の設定を目的に、屋外縮小模型都市実 験を行つた。バルク輸送係数は乱流熱輸送量を算定する 上で重要なパラメーターであるが、現在、都市表面にお けるバルク輸送係数の報告例は非常に少なく67)、また 不確定要素が多い。都市表面におけるバルク輸送係数の 知見の蓄積、簡易都市キャノピーモデルへ適用すること 


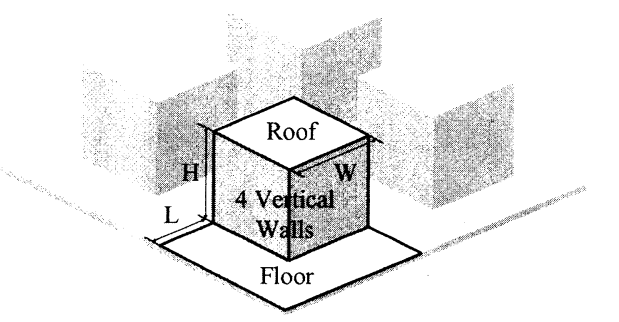

図1 都市幾何構造

が可能な汎用的なモデル化は今後行っていくべき重要な 課題である。本論では屋外縮小模型都市実験により、熱 収支残差法を用いて都市構成面別のバルク輸送係数の算 定を行った。

\section{3次元簡易都市キャノピーモデル(SUMM)}

\section{（1）都市幾何構造}

SUMMで対象とする建物配列を図1に示す。各建物は 高さ、床面幅が均一な直方体であり、整列に配置されて いる。都市構成面(解像度)は床面、屋根面、及び各鉛直 壁面(北、東、南、西面)である。このような規則的な建 物配列を仮定すると、都市幾何構造は以下の式(1),(2)で 表される建蔽率 $\left(\lambda_{P}\right)$ 、フロンタルエリアインデックス $\left(\lambda_{f}\right)$ を用いて一義的に表すことができる。

$$
\begin{aligned}
& \lambda_{P}=W^{2} /(W+L)^{2} \\
& \lambda_{f}=W \times H /(W+L)^{2}
\end{aligned}
$$

ここに、 $W$ は建物床面幅、 $H$ は建物高さ、 $L$ は街路幅 である。

\section{(2) 短波放射収支計算}

SUMMでは放射の多重散乱過程を解く際に解像度の制 約から、都市表面は鏡面反射成分を持たない乱射面であ ると仮定している。実都市では、一部(空等)でこの仮定 が成り立たないが、大部分の都市構成素材は鏡面反射成 分をほぼ持たないことが知られており、この仮定は近似 的に成立するものと考えられる。各構成面内では放射特 性が均一であるとし、かつ乱射面を仮定すると、短波放 射の多重散乱過程は以下のように表すことができる。

まず、各面( $i$ 面)における1回目の反射 $\left(R_{r e f}(i, 1)\right)$ 、吸収 $\left(R_{a b}(i, 1)\right)$ 成分は式(3),(4)で表せる。

$$
\begin{aligned}
& R_{r e f}(i, 1)=a(i) R_{S}(i)+b(i) R_{d 0} V(i, s k y) \\
& R_{a b}(i, 1)=(1-a(i)) R_{S}(i)+(1-b(i)) R_{d 0} V(i, s k y)
\end{aligned}
$$

ここに、 $i$ は構成面番号であり、1〜 6まで順に4鉛直壁 面、床面、屋根面を表している。 $R_{S}(i)$ は単位 $i$ 面に入 射する直達短波放射量、 $V(i, s k y)$ は $i$ 面における天空率、
$R_{d 0}$ は単位水平面に入射する天空散乱光成分、 $a(i), b(i)$ はそれぞれ直達光、散乱光(天空散乱光、無指 向性反射成分)に対する要素面アルベドである。2回目以 降の多重散乱に対しては無指向性反射光成分のみを考慮 し、 $N$ 回目の各面 $\left(i\right.$ 面)における反射 $\left(R_{r e f}(i, N)\right)$ 、吸収 成分 $\left(R_{a b}(i, N)\right)$ は $N-1$ 回目の各面 $(j$ 面)での反射成分 $\left(R_{r e f}(j, N-1)\right)$ を用いて以下の式(5)、(6)で表せる。

$$
\begin{aligned}
& R_{r e f}(i, N)=b(i) \sum_{j=1}^{6} R_{r e f}(j, N-1) V(j, i) \\
& R_{a b}(i, N)=(1-b(i)) \sum_{j=1}^{6} R_{r e f}(j, N-1) V(j, i)
\end{aligned}
$$

ここに、 $V(i, j)$ は面から $j$ 面に対する形態係数である。 考慮する多重反射回数 $N_{\max }$ 回後の単位 $i$ 面当たりの短 波放射の総反射 $\left(R T_{r e f}(i)\right)$ 、吸収量 $\left(R T_{a b}(i)\right)$ は以下の 式(7)、(8)で表せる。

$$
\begin{aligned}
& R T_{r e f}(i)=\sum_{N=1}^{N \max } R_{r e f}(i, N) \\
& R T_{a b}(i)=\sum_{N=1}^{N \max } R_{a b}(i, N)
\end{aligned}
$$

以上から、都市キャノピー全体の総短波反射量 $(S \uparrow)$ は 式(9)で計算することができる。

$$
\begin{aligned}
S \uparrow & =\left[R_{S 0} \times S_{\text {lot }}-\sum_{i=1}^{6} R T_{a b}(i) S_{i}\right] / S_{\text {lot }} \\
& =\left[\sum_{i=1}^{6} R T_{\text {ref }}(i) V(i, s k y) S_{i}\right] / S_{\text {lot }}
\end{aligned}
$$

ここに、 $S_{i}$ は $i$ 面の面積, $S_{l o t}\left(=(L+W)^{2}\right)$ は単位領域 の水平面面積である。以上の放射収支計算において必要 となる各パラメーター $(a(i) 、 b(i)) 、 V(i, s k y) 、$ $\left.V(i, j)) 、 R_{S}(i)\right)$ の算定法はKanda et al (2004) ${ }^{5)}$ に従って いる。特に3次元幾何構造の複雑な日向 -日陰形成 $\left(R_{S}(i)\right)$ を解析的に求めることは難しいが、SUMMでは 任意の幾何構造 $\left(\lambda_{P}, \lambda_{f}\right)$ 、太陽位置における日向・日陰 部分の面積を求める解析解を、幾何パラメーター

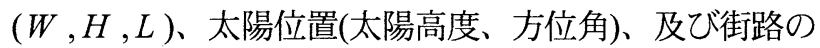
南北軸からの傾きの関数として導出して用いている。こ れらの解析解の詳細な導出方法はKanda et al (2004) $)^{5)}$ を参 照されたい。

\section{（3）長波放射収支計算}

長波放射収支計算においても短波放射収支計算同様に 構成面間の多重散乱過程を解くが、各面における1回目 の反射時には天空起源の無指向性入射長波放射及び、各 構成面の表面温度に起因して放出される赤外放射を考慮 
する必要がある。すなわち、 $i$ 面における1回目の反射 $\left(L_{r e f}(i, 1)\right)$ 、吸収成分 $\left(L_{a b}(i, 1)\right)$ は以下の式 $(10) 、(11)$ で 表せる。

$$
\begin{aligned}
& L_{r e f}(i, 1)=(1-\varepsilon(i)) L \downarrow V(i, s k y)+\sigma \varepsilon(i) T_{S}(i)^{4} \\
& L_{a b}(i, 1)=\varepsilon(i) L \downarrow V(i, s k y)-\sigma \varepsilon(i) T_{S}(i)^{4}
\end{aligned}
$$

ここに、 $L \downarrow$ は下向長波放射量、 $\varepsilon(i)$ は $i$ 面の射出率、 $\sigma$ はステファンボルツマン定数、 $T_{S}(i)$ は $i$ 面の平均表 面温度である。なお、射出率には入射角依存性を考慮せ ず、一定值を与えている。短波放射過程同様、 $N$ 回目 の反射 $\left(L_{r e f}(i, N)\right)$ 、吸収成分 $\left(L_{a b}(i, N)\right)$ は $N-1$ 回目の 反射成分 $\left(L_{r e f}(i, N-1)\right)$ を用い、式(12)、(13)で表せる。

$$
\begin{aligned}
& L_{r e f}(i, N)=\sum_{j=1}^{6}(1-\varepsilon(i)) L_{r e f}(j, N-1) V(i, j) \\
& L_{a b}(i, N)=\sum_{j=1}^{6} \varepsilon(i) L_{r e f}(j, N-1) V(i, j)
\end{aligned}
$$

考慮する多重反射回数 $N_{\text {max }}$ 回後の $i$ 面における総長波 放射反射量 $\left(L T_{r e f}(i)\right)$ 、吸収量 $\left(L T_{a b}(i)\right)$ は式(14)、(15)で 表せる。

$$
\begin{aligned}
& L T_{r e f}(i)=\sum_{N=1}^{N \max } L_{r e f}(i, N) \\
& L T_{a b}(i)=\sum_{N=1}^{N \max } L_{a b}(i, N)
\end{aligned}
$$

以上から、単位水平面当たりの上向き長波放射量 $(L \uparrow)$ は以下の式(16)で計算できる。

$$
\begin{aligned}
L \uparrow & =\left[L \downarrow \times S_{\text {lot }}-\sum_{i=1}^{6} L T_{a b}(i) S_{i}\right] / S_{l o t} \\
& =\left[\sum_{i=1}^{6} L T_{\text {ref }}(i) V(i, s k y) S_{i}\right] / S_{l o t}
\end{aligned}
$$

\section{(4) 顕熱輸送量の計算}

顕熱輸送量の算出には、従来の簡易都市キャノピーモ デル同様、輸送抵抗型のモデル化を行っている(図2(a))。 すなわち、各構成面 $(i$ 面)から上空への顕熱輸送量 ( $H(i))$ は式(17)で表されるバルク式により表現できる。

$$
H(i)=c_{p} \rho C_{H}(i) U_{a}\left(T_{a}-T_{S}(i)\right)
$$

ここに、 $c_{p}$ は空気の定圧比熱 $\rho$ は空気密度、 $U_{a}, T_{a}$ はそれぞれ上空基準高度 $\left(z_{a}\right)$ における風速、気温、

$C_{H}(i)$ は $i$ 面と基準高度間のバルク輸送係数である。ま た、都市キャノピー全体の顕熱輸送量 $(H)$ は各構成面か らの顕熱輸送量の連続条件より、以下の式(18)で表せる。

$$
H=\left[\sum_{i=1}^{6} H(i) S_{i}\right] / S_{l o t}
$$

一方、都市キャノピー全体の顕熱輸送量 $(H)$ をバルク式 で記すと式(19)となる。

$$
H=c_{p} \rho C_{H} U_{a}\left(T_{a}-T_{H}\right)
$$

式(19)は、都市の幾何構造(凸凹)を空気力学的に考慮し た仮想的な平板(図2(b))からの顕熱輸送量に対するバル ク式とみなすことができる。ここに、 $C_{H}$ は都市キャノ ピー全体のバルク輸送係数、 $T_{H}$ は空気力学的に都市を 代表する温度である(空気力学的都市代表温度)。また、 $C_{H}, T_{H}$ は、式(17)、(18)、(19)より以下の式(20)、(21)で 表せる。

$$
\begin{aligned}
C_{H} & =\left[\sum_{i=1}^{6} C_{H}(i) S_{i}\right] / S_{\text {lot }} \\
T_{H} & =\left[\sum_{i=1}^{6} T_{S}(i) C_{H}(i) S_{i}\right] / C_{H} S_{l o t}
\end{aligned}
$$

以上において、バルク輸送係数 $\left(C_{H}(i), C_{H}\right)$ はモデル精 度に大きく影響する重要なパラメーターである。従来、 簡易的な都市キャノピーモデルでは、バルク輸送係数の 設定にはモニン・オブコフ相似則を用いるか、或いは壁 面における伝熱現象を近傍風速の関数としてあてはめる 方法が一般的である。しかしながら、本来、モニン・オ ブコフ相似則は局所的な鉛直壁面に適用することはでき ず、都市建物群を粗度とみなして積算された条件でしか 適用することができない。このため、本論ではバルク係 数の設定には以下の2段階の手法を用いている。

まず、第一に都市キャノピー全体のバルク係数 $C_{H}$ を 式(22)で表せるモニン・オブコフ相似則により決定する。

$$
C_{H}=\frac{\kappa^{2}}{\left(\int_{Z_{0 I} / L}^{\left(Z_{u}-T_{u}\right) / I} \Phi_{H}(\varsigma) \frac{d \varsigma}{\varsigma}\right)^{2}}
$$

ここに、 $\kappa$ はカルマン定数、 $L$ はモニン・オブコフ長 さ、 $\zeta$ は無次元長さ $\left(=\left(z-z_{d}\right) / L\right) 、 \Phi_{H}(\zeta)$ は熱に対 する普遍関数、 $z_{0}, z_{0 T}, z_{d}, z_{a}$ はそれぞれ、運動量に 対する粗度長、熱に対する粗度長、ゼ口面変位、基準高 度である。 $z_{0}$ 及び $z_{d}$ は幾何パラメーター $\lambda_{p} 、 \lambda_{f}$ を用 い、マクドナルドの式(Macdonald et al., 1998) ${ }^{8}$ により 半理論的に決定する。熱に対する粗度長 $z_{0 T}$ は実測より 得られた $\ln \left(z_{0} / z_{0 T}\right)$ の值を用いて決定する。本論で は、東京の住宅地において長期観測より得られた年平均 值”を用いている(式(23))。

$$
\ln \left(z_{0} / z_{0 T}\right)=6.0
$$


(a)

(b)

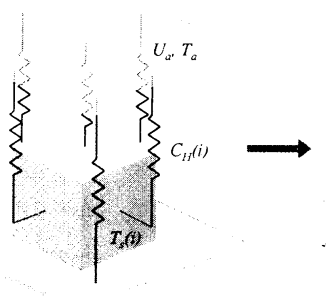

図2 輸送抵抗型顕熱輸送量のモデル化

以上の式(22)より決定された $C_{H}$ を、第二段階として各 構成面の局所バルク輸送係数 $\left(C_{H}(i)\right)$ に分配する。ここ で、 $C_{H}(i)$ の相対的な比率が必要となるが、本論では屋 根面における值で正規化された各要素面の $C_{H}(i)$ を、第 3章で紹介する屋外縮小模型都市実験より決定し、用い ている。

\section{（4）表面温度と熱収支の計算}

都市各構成面の表面温度は、壁面内鉛直1次元の熱伝 導を仮定し、以下の式(24)で表せる熱伝導方程式により 予測する。

$$
\frac{\partial T_{\text {in }}(i)}{\partial z}=\frac{1}{\rho(i) c(i)}\left(\lambda(i) \frac{\partial^{2} T_{i n}(i)}{\partial z^{2}}\right)
$$

ここに、 $\lambda(i)$ は $i$ 面の熱伝導率、 $\rho(i) c(i)$ は $i$ 面の体積 熱容量、 $T_{i n}(i)$ は $i$ 面の壁面内部温度である。式(24)を解 く際、地表面における境界条件には式(25)で表せる、各 構成面 $(i$ 面)の熱収支式を与える。

$$
R T_{a b}(i)+R L_{a b}(i)-H(i)-L E(i)=G(i)
$$

ここに、G(i) は $i$ 面表面における地中伝導熱であり、式 (25)の左辺各項は上記した2章(1)〜(3)節より予測する。 一方、壁面内部の境界条件(室内温度)には本来別途予測 した值を用いる必要があるが、本論では屋外模型都市実 験より得られた観測値を用いている。以上の式(24)、 (25)より計算した各構成面の地中伝導熱 $(G(i))$ より、都 市キャノピー全体の地中伝導熱は以下の式(26)で表せる。

$$
G=\left[\sum_{i=1}^{6} G(i) S_{i}\right] / S_{l o t}
$$

\section{3. 屋外模型都市実験}

\section{(1) 実験概要}

SUMMの検証、及び未知モデルパラメーターの検討を 目的とし、屋外環境下で縮小模型都市実験を行った(図3)。 観測には三重県松阪市( $\left.34^{\circ} 50^{\prime} \mathrm{N}, 136^{\circ} 50^{\circ} \mathrm{E}\right)$ の休耕田を利 用し、2002年11月より2004年3月まで期間、継続的に観 測を行った。都市構成素材は一律均一なコンクリート素

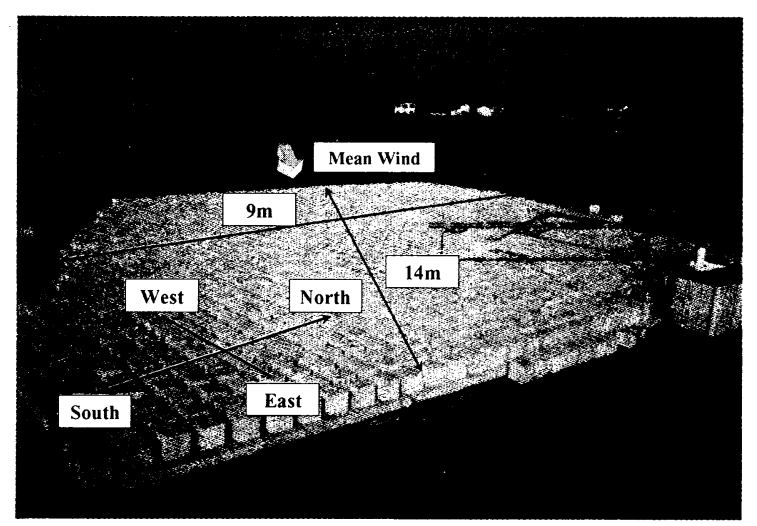

図3 屋外縮小模型都市実験 (1/50スケール) (a)

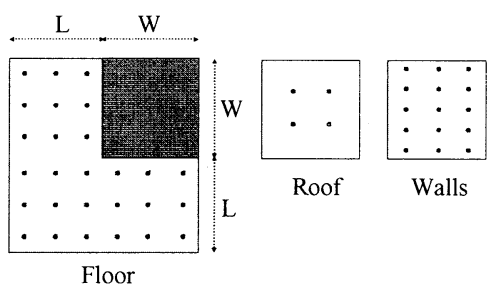

図4 表面温度 (a)、地中伝導熱 (b) の測定
材であり、 $12 \times 9 \mathrm{~m}^{2}$ の領域に、建物と見立てた一辺 $0.15 \mathrm{~m}$ の立方体コンクリートブロックを整列に配置して

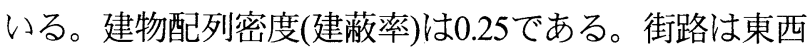
(南北)方向を向いており、これは主流風向(西北西)と概 ね一致している。また、十分に発達した内部境界層を確 保するために、測定場所は、風上側から測り風下約 $10 \mathrm{~m}$ (約70H)の場所に設定した。なお、気温の鉛直プロファ イル観測(Type E熱電対、 $\varphi 0.05 \mathrm{~mm}$ 使用)より、内部境界 層の発達高度はおおよそ $2 \mathrm{H}$ 3H と見込むことができる。 都市キャノピー上端での放射収支 $(\mathrm{S} \downarrow$, $\mathrm{S} \uparrow, \mathrm{L} \downarrow, \mathrm{L} \uparrow)$ は床面か ら $0.7 \mathrm{~m}$ の高度に設置した長短波放射計(Eko,MR40)によ り測定し、内部境界層内風速、風向は床面から $0.4 \mathrm{~m}$ (2.7H)の高度に設置した超音波風速計(Kaijo-WA590,8Hz) を用いて測定した。表面地中伝導熱 $(\mathrm{G})$ の測定には薄型 の熱流板(Captec HF-300, 0.4mm厚)を用い、これを各構成 面に隙間なく貼り付けた。表面は放射特性を周囲とあわ せるために、2 $\mathrm{mm}$ 厚でモルタル加工を施している(図 4(b))。表面温度測定には熱電対(Type T, $\varphi 0.2 \mathrm{~mm}$ )を用い、 各構成面に複数点配置した(図4(a))。表面は熱流板同様、 モルタル加工を施している。

\section{(2) バルク輸送係数}

\section{a) 局所顕熱輸送量の算出法}

式(17)よりバルク輸送係数 $\left(C_{H}(i)\right)$ を算出するために は、各構成面の局所的な顕熱輸送量 $(H(i))$ を求める必要 がある。本論では $i$ 面における局所顕熱輸送量は以下の 式(27)で表せる $i$ 面の熱収支式より、残差項として算出 している。 
表1 バルク輸送係数算出の閾値

\begin{tabular}{c|c|c|c}
\hline $\begin{array}{c}\text { 参照風速 } \\
U_{a}\left(m \cdot s^{-1}\right)\end{array}$ & $\begin{array}{c}\text { 風向 } \\
(\mathrm{deg})\end{array}$ & $\begin{array}{c}\text { 温度差 } \\
\Delta T(K)=T_{a}-T_{s}(i)\end{array}$ & $\begin{array}{c}\text { 安定度 } \\
R b=\frac{g H}{\left(T_{a}+273.15\right)} \frac{\left(T_{a}-T_{c}\right)}{U_{a}{ }^{2}}\end{array}$ \\
\hline$U_{a}>1.0$ & $270-360$ & $|\Delta T|>0.5$ & $|R b|>0.025$ \\
\hline$T_{c}:$ Complete surface temperature $\quad=\left[\sum_{i=1}^{6} T_{s} S_{i}\right] / S_{l o t}$
\end{tabular}

$$
H(i)=R T_{a b}(i)+R L_{a b}(i)-G(i)-\iota E(i)
$$

ここで、式(27)の右辺第1,2項(正味放射量)には厳密放射 解析モデル ${ }^{5)}$ を用いて詳細に計算した結果を用い、右辺 第3項(地中伝導熱)は薄型熱流板により直接測定した值を 用いている。右辺第4項の潜熱輸送量は無視している。 一般にコンクリート素材の潜熱を完全に無視し得るかは 議論の余地を残すが、式(27)で熱収支を考慮する局所面 の潜熱輸送量は熱流板上に加工された極めて薄いモル夕 ルから出るものであり無視することができる。このため 潜熱による誤差は式(27)の右辺第2項に現れる。つまり、 潜熱が若干量出ている周囲のコンクリートの表面温度が、 潜熱輸送の無い、熱流板を貼り付けた面の表面温度と若 干異なることが、2回目以降の長波放射多重散乱計算に 影響し、2次的な誤差となる。しかしながら、このよう な影響は晴天日が数日間続いた後は非常に小さくなるこ とが考えられる。このため、本論では降雨後3日以上経 た後の観測データのみを解析の対象としている。

\section{b) バルク輸送係数の算出結果}

局所的なバルク輸送係数は近傍風速、風向(壁面に向 かう流れ、沿う流れ等)、局所的な安定度等に密接に関 連するものの、本論で取り扱う自然風、3次元幾何構造 下では上空風の風向(又は風向の振れ)、風速、日射条件 (日向、日陰形成)等の変化により壁面近傍気流性状は極 めて複雑に変化する。これに加えて、実都市における観 測では、局所面の対流熱伝達率-近傍風速の関係は観測 サイト、基準高度の取り方により異なることが報告され ている ${ }^{10)}$ 。このため、バルク式の風速参照位置を一義的 に定め、局所的なバルク輸送係数の絶対值を近傍気流に より評価し、シミュレーションモデルへの適用するのは 現状では困難である。そこで本論では2章(4)節に記した ように、都市構成面毎のバルク輸送係数を上空風速で整 理し、この相対值のみをシミュレーションモデルへ適用 する手法をとっている。ここで、本実験で算出した日中 のバルク輸送係数は大気安定度の影響によるばらつきが 大きく、統計的に有意なアンサンブル平均を取るための サンプル数に欠けている。このため、各測定デー夕は比 較的中立に近い夜間(0時〜日の出時刻)のデー夕の夕を用 い、これを第一近似として整理した。なお、デー夕品質 を保つため、バルク輸送係数算出の閾値は表1の様に設 定している。鉛直壁面に対しては近傍気流性状が大きく

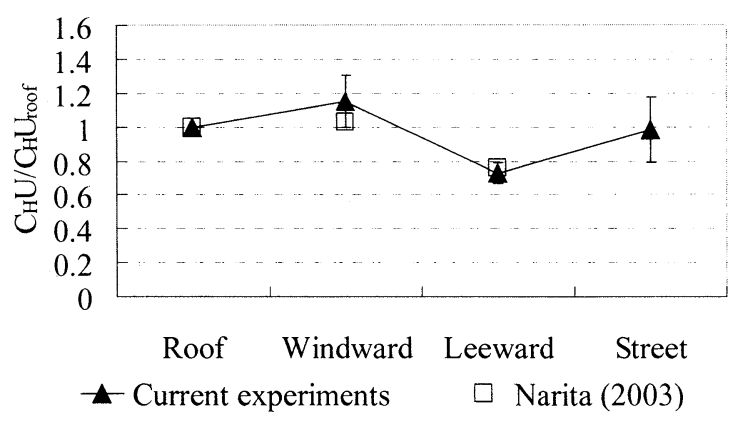

図5 顕熱交換速度 $\left(C_{H} U\right)$ の算出結果

異なると考えられる風上面(北、西面)、風下面(東、南 面)に2分し整理した。図5は算出した顕熱輸送速度 $\left(C_{H}(i) U\right)$ を、風向による影響をほとんど受けない屋根 面の值で正規化した結果であり、これを風洞実験 (Narita,2003) ${ }^{6)}$ による結果と比較したものである。

\section{4. モデル検証}

モデル検証に幾何構造等の条件がSUMMと厳密に一致 しない実都市における観測デー夕を用い、構成面別の系 統的なモデル検証を行うことは難しい。このため、本論 では3章で紹介した屋外縮小模型実験による構成面別熱 収支、表面温度の測定結果を用いてSUMMの検証を行つ た。ここで、放射過程以外は縮小模型と実都市との間に 物理的な相似性が保たれないため、以下に示す各グラフ を量的に議論することは重要な意味を持たないが、縮小 模型実験によりSUMMの再現性が確認されれば、モデル 内で実スケールへ抎張することは容易である。

図6、7、8、はそれぞれキャノピー熱収支、構成面別 顕熱輸送量、表面温度の検証結果である。各実線は実測 值であり、各点線はSUMMによるシミュレーション結果 を示している。まず、SUMMによる正味放射量の計算結 果は観測結果を良好に再現している(図6)。若干の差異は 解像度によるもの、及び、表面温度のシミュレーション 結果によるものと考えられる。顕熱輸送量、地中伝導熱 及び表面温度に対しても部分的には量的な差異が見られ るが、日変動の傾向は概ね観測結果を再現している。部 分的に見られる誤差要因を明確に示すことは難しいが、 主な要因としては以下が挙げられる。

i ) バルク輸送係数のモデル化の問題

ii）壁面内における鉛直一次元熱伝導の仮定 まず、i )に関して、本論ではバルク輸送係数に夜間、 中立に近い条件下で得られた観測結果のみを解析に用い、 鉛直壁面のバルク輸送係数は風上面、風下面で大き $<2$ 分して值を用いている。このため、日中、大気安定度が 不安定になる条件下、又は風向が頻繁に振扢る様な条件 下では本論で用いたバルク輸送係数が比較的大きな誤差 要因となる。次に、ii)に関して、本論でモデル検証に 

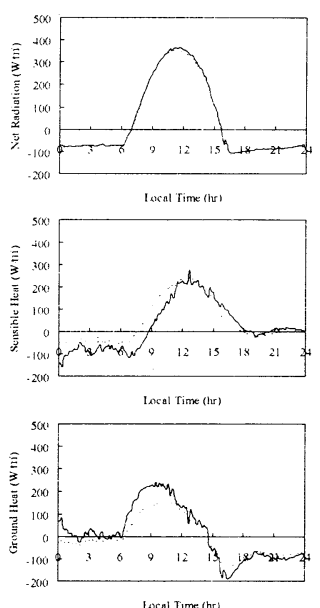

図6 キャノピー熱収支 の検証結果
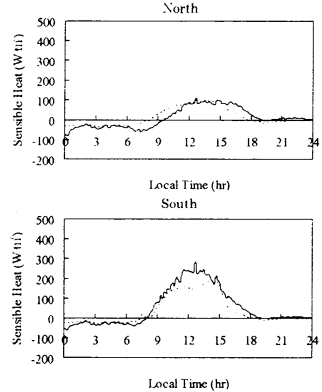

Local Time (his
Floor

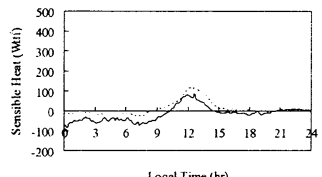

local Time (hir

図7 構成面別顕熱輸送量の検証結果

Local Time
Roof

local Time (hr)

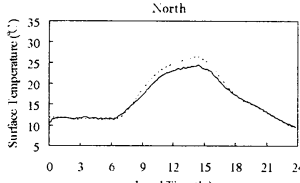

Localt time (inf
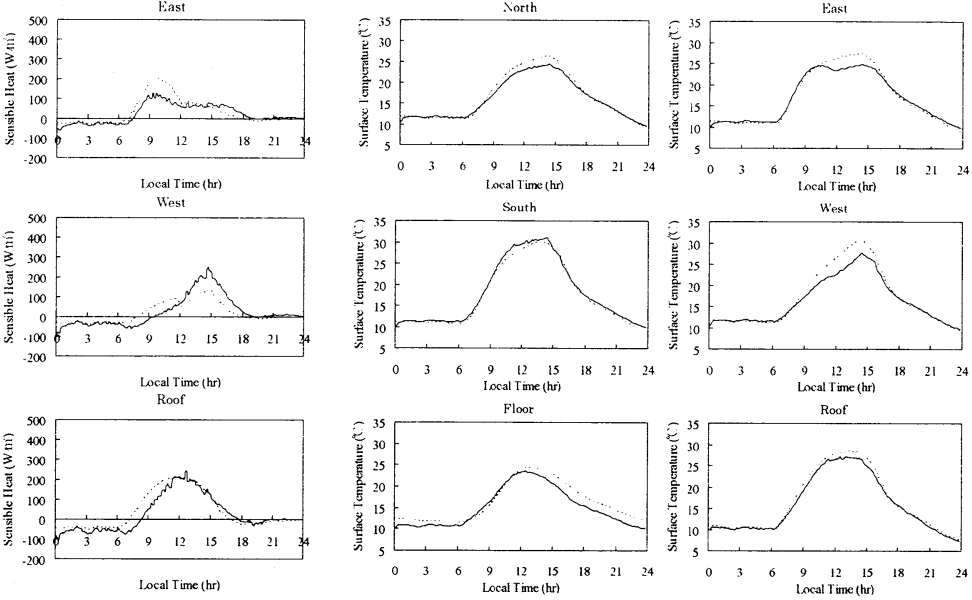

図8 構成面別表面度の検証結果
用いた縮小模型都市実験は、建物サイズが極めて小さく、 壁面内の3次元的な熱搪散を完全に無視することができ ない(例えば1構成面より供給された熱が他の構成面に及 ぼす影響等)。このため、簡易的な一次元熱伝導の仮定 を用い、縮小スケールの熱伝導を解く際には、3次元熱 拡散の影響が大きくなる日中(特に建物の局所的な加熱 が始まる午前中)に誤差が顕著に現れることが考えられ る。これらに対しては今後さらに検討を進め、精度向上 を図りたい。

\section{5. 結論}

本論では3次元幾何構造を対象とした簡易都市キャノ ピーモデルを提案し、屋外縮小模型実験により都市構成 面別のバルク輸送係数の算定、及びモデル検証を行った。 バルク輸送係数は熱収支残差法を用いて算出し、大気安 定度が中立に近い夜間の測定デー夕を用いて風上面、風 下面、屋根面、床面別に整理した。算出したバルク輸送 係数を屋根面の值で正規化した結果は風洞実験による実 験結果と概ね一致する傾向を示した。SUMMによるシ ミュレーション結果は、観測結果と一部で若干の差異が 見られたが、日変動パターンを良好に再現した。

謝辞 : 本研究は科学技術振興事業団戦略的基礎研究推進 事業(代表:神田学)による財政的援助を受けた。ここに謝 意を表す。

\section{参考文献}

1) Kusaka, H., Kondo, H., Kikegawa, Y., and Kimura, F : A Simple Single-layer Urban Canopy Model for Atmospheric Models: Comparison with Multi-layer and Slab Models, Boundary-Layer Meteorol. 101, pp 329-358, 2001.
2) Masson, V. : A Physically-based Scheme for the Urban Energy Budget in Atmospheric Models. Boundary-Layer Meteorol. 94, pp 357-397, 2000.

3) Martilli, A., Clappier, A. and Rotach, M.W. : An Urban Surface Exchange Parameterization for Mesoscale Models. BoundaryLayer Meteorol. 104, pp 261-304, 2002.

4) 田中賢治・池淵周一：都市域水体をも考慮した蒸発散モデ ルの構築とその琵琶湖流域への適用, 京大防災研究所年報, 73 B-1, pp 299-313, 1994.

5) Kanda, M., Kawai, T. and Nakagawa, K : Simple Theoretical Radiation Scheme for Regular Building Array. Boundary-Layer Meteorol. (in press), 2004.

6) Narita, K. : Wind Tunnel Experiment on Convective Transfer Coefficient in Urban Street Canyon. $5^{\text {th }}$ Int Conf Urban Climate Lots Poland, O21.2 (CD-ROM), 2003.

7) Barlow, J. F. and Belcher, S.E. : A Wind Tunnel Model for Quantifying Fluxes in The Urban Boundary Layer. BoundaryLayer Meteorol., 104, pp 131-150, 2002.

8) Macdonald, R.W., Griffiths, R.F., and Hall, D.J. : An Improved Method for the Estimation of Surface Roughness of Obstacle Arrays. Atmos. Environ. 32, pp 1857-1864, 1998.

9) Moriwaki, R. and Kanda M. : Seasonal and Diumal Fluxes of Radiation, Heat, Water Vapor and $\mathrm{CO}_{2}$ Over a Suburban Area : $J$. Appl. Meteorol. (in press), 2004.

10) Hagishima, A., Tanimoto, J. and Narita, K. : Review of Experimental Research on the Convective Heat Transfer Coefficient of Urban Surfaces. Boundary-Layer Meteorol. (submitted), 2004.

(2004.9. 30 受付) 